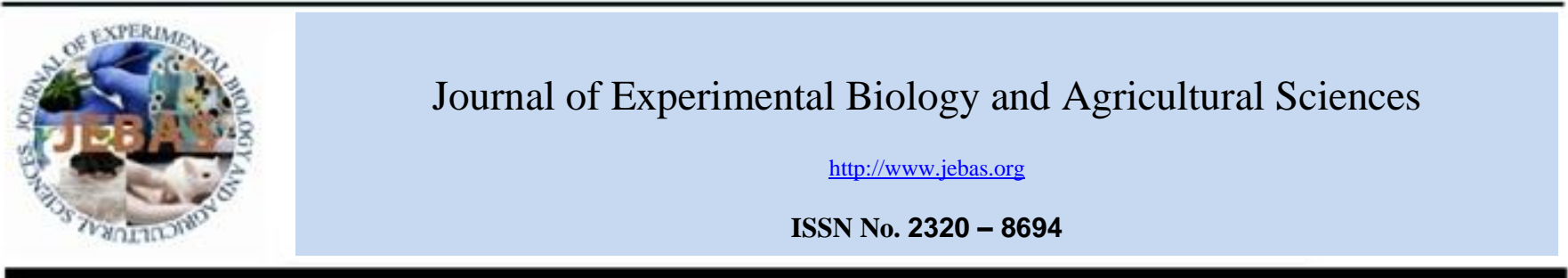

\title{
EFFECT OF THE LENGTH OF THE FLOWERING-HARVEST INTERVAL ON THE RIPENING AND QUALITY OF THE 'KENT' MANGO IN CÔTE D'IVOIRE
}

\author{
Jean Mathias Konan Koffi ${ }^{1,2^{*}}$, Dogniméton Soro $^{2}$, Lassina Fondio ${ }^{1}$, Achille N'da Adopo ${ }^{1}$, Éric \\ Malézieux ${ }^{3,4}$, Emile Faye ${ }^{3,4,5}$
}

\author{
${ }^{1}$ National Center for Agricultural Research (CNRA), Regional Direction of Korhogo/Lataha Research Station, BP 856 Korhogo, Côte d'Ivoire \\ ${ }^{2}$ University Jean Lorougnon Guédé (UJLoG), Daloa, P.O. Box 150, Côte d'Ivoire \\ ${ }^{3}$ CIRAD, UPR HortSys, F-34398 Montpellier, France \\ ${ }^{4}$ HortSys, Univ Montpellier, CIRAD, Montpellier, France \\ ${ }^{5}$ ISRA, Center for Horticultural Development, Dakar 14000, Sénégal
}

Received - January 25, 2021; Revision - March 18, 2021; Accepted - April 09, 2021

Available Online - April 25, 2021

DOI: http://dx.doi.org/10.18006/2021.9(2).138.146

KEYWORDS
Côte d'Ivoire
Flowering
Mangifera indica L.
Maturity
Harvest

\begin{abstract}
The physiological stage of mango maturity at harvest affects fruit quality at the time it is commercialized. The objective assessment of the mango maturity stage at harvest remains a challenge because of the multiple interactions between the visual aspect, the physicochemical composition, and the morphology of the fruit. This study aims to quantify the optimal harvest date to guarantee the maturity and quality of mango cv. 'Kent'. In this study, which took place in Korhogo in northern Côte d'Ivoire, the maturity stage and the quality of fruits were measured on 240 Kent mangoes harvested at four different harvest dates (90, 95, 100, and 105 days after flowering). A morphological, physical, and chemical characterization (length, width, mass, soluble sugar content, dry matter, skin appearance, and mass loss) was carried out at each date on 30 fruits at harvest and 30 fruits after ripening at room temperature. The number of days necessary for ripening was quantified. The results showed that the optimal harvest date is 100 days after flowering for Kent mangoes in Côte d'Ivoire. Mangoes harvested at this date developed better organoleptic characteristics (less wrinkled skin, lower mass losses, and a shorter ripening time). Assessment of the harvest date, guaranteeing better ripening of the fruit, is of utmost importance for organizing harvests in the mango sectors in West Africa, and especially in Côte d'Ivoire.
\end{abstract}

* Corresponding author

E-mail: jeanmathiaskonan@gmail.com (Jean Mathias Konan Koffi)

Peer review under responsibility of Journal of Experimental Biology and Agricultural Sciences.

Production and Hosting by Horizon Publisher India [HPI] (http://www.horizonpublisherindia.in/).

All rights reserved.
All the articles published by Journal of Experimental Biology and Agricultural Sciences are licensed under a Creative Commons Attribution-NonCommercial 4.0 International License Based on a work at www.jebas.org.

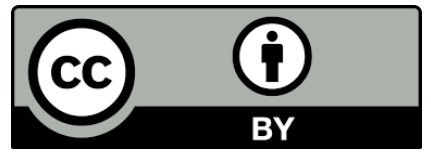




\section{Introduction}

Mango (Mangifera indica L.), the $5^{\text {th }}$ most cultivated fruit in the world, is produced in large quantity in Côte d'Ivoire, the leading African mango exporting country and the $3^{\text {rd }}$ worldwide supplier of the European market (Kouamé et al., 2020). West Africa, a major supplier of the European market with $10.8 \%$ of the worldwide production, has experienced the greatest increase rate of mango production worldwide over this last decade (Mitra, 2016). The demand of mango is continuously increasing on export markets because of its attractive appearance and its organoleptic, energy, and nutritional qualities (Abu et al., 2021). Moreover, due to its high content in vitamins $\mathrm{C}$ and $\mathrm{A}$, mango fruit contributes to limiting vitamin A deficiency also (Cortés et al., 2016). Moreover, since mangoes are produced during the hunger gap period, they are of critical importance for food safety in sub-Saharan countries (Parrot et al., 2018).

Despite all of these advantages, the development of the mango trade faced technical obstacles linked to the perishable nature of the fruit and the difficulty of objectively assessing the physiological maturity stage at harvest, of utmost importance for a climacteric fruit like mango (Nordey et al., 2019). The taste, the physical appearance, the chemical composition (soluble sugar content (SSC), dry matter (DM), titratable acidity (TA), etc.), and the post-harvest conservation time of mangoes depend on their level of maturity at harvest (Ibrahima et al., 2020; Diop et al., 2021). Fruits harvested before maturity do not ripen uniformly, even for fruits from the same tree and/or orchard, and may have wrinkled skin or variable total SSC (Nordey et al, 2016; Abu et al., 2021). Moreover, the level of physiological maturity in mango fruits at harvest influences their suitability for transport, conservation, ripening and, consequently, the final quality of the fruits proposed to consumers (Brecht, 2020; Farina et al., 2020; Bender et al., 2021). Not even ethylene and acetylene treatments of immature fruits will allow them to reach complete maturation with a satisfactory taste and aroma (Cissé et al., 2020). On the other hand, fruits harvested at a late stage of maturity incur shorter conservation times and a greater sensitivity to disease (Farina et al., 2020).

Overall, external morphological criteria such as fruit size, skin color, shoulder growth, and fruit shape help to estimate the maturity stage of the harvest of mango trees (Brecht, 2020). Other attempts have been made to establish a maturity index for mango in terms of density and firmness, but the inconsistency of these parameters and the diversity of mango cultivars limits its use as a criterion to predict maturity (Subedi et al., 2007). Further, certain chemical parameters such as SSC, TA, starch, phenolic compounds, carotenoids, and DM content have also been used together with morphological criteria to quantify fruit maturity
(Nambi et al., 2017; Abu et al., 2021). Generally speaking, an SSC of over $8 \%$ and acidity of approximately $1 \%$ are indices that can be used to assess mango maturity (Subedi et al., 2007). However, most of them are of a chemical or physiological nature and must be determined in a technical laboratory with the destruction of the fruit. Many studies have been carried out to design tools that quantify fruit maturity and quality using non-destructive optical or physical methods (Nordey et al., 2019).

In this context, limited informations are available on the effect of harvest date on mango quality and ripening have been carried out in West Africa. At present, few reliable and non-destructive methods exist to evaluate the degree of maturity of mangoes in the field (Raghavendra et al., 2021). Till today, in view of the increase in production and the number of fruits rejected at harvest due to immaturity, the development of reliable and adaptable tools to estimate the optimal fruit harvest date is key to organize harvests in the mango sectors in West Africa, and especially in Côte d'Ivoire.

The difficulty of assessing the stage of physiological maturity at harvest for a climacteric fruit such as mango led to this study. The main objective of this study was to study the relationships between the physicochemical parameters (DM, $\mathrm{SSC}$, etc.) and the harvest date of mangoes cv. 'Kent' in northern Côte d'Ivoire. This cultivar is the most popular mango cultivars intended for export because of its appealing color and, above all, its non-fibrous pulp.

\section{Materials and Methods}

\subsection{Study area}

The experiment was carried out from January to May 2019 in a mango orchard on farmland in Lavononkaha $\left(09^{\circ} 38^{\prime} \mathrm{N}\right.$ and $5^{\circ} 56^{\prime} \mathrm{O}$ ), $8 \mathrm{~km}$ from Korhogo, the seat of the Poro region, in northern Côte d'Ivoire (Figure 1). The orchard, which covers an area of 10 ha, is located at an altitude of 336 meters. Kent mangoes are the most commonly grown in the orchard. The orchard is a fairly well-structured export orchard, and the trees are planted in rows with a spacing of $10 \mathrm{~m} \times 10 \mathrm{~m}$ (100trees. ha $\left.{ }^{-1}\right)$. The orchard is surrounded by a cashew tree hedge and benefits from sanitary maintenance against fruit flies, bacteriosis, and anthracnose. Neither irrigation nor fertilization is used in the orchard, and flowers/fruits are not removed. The climate in the region is of the Sudanese type with two seasons: a dry season from November to April, and a rainy season from May to October. Annual average rainfall is $1400 \mathrm{~mm}$ in a wet year, and $1000 \mathrm{~mm}$ in a dry year. The natural vegetation consists of wooded savannah. The soils are ferrolitic, moderately to highly desaturated (Djaha et al., 2014). 


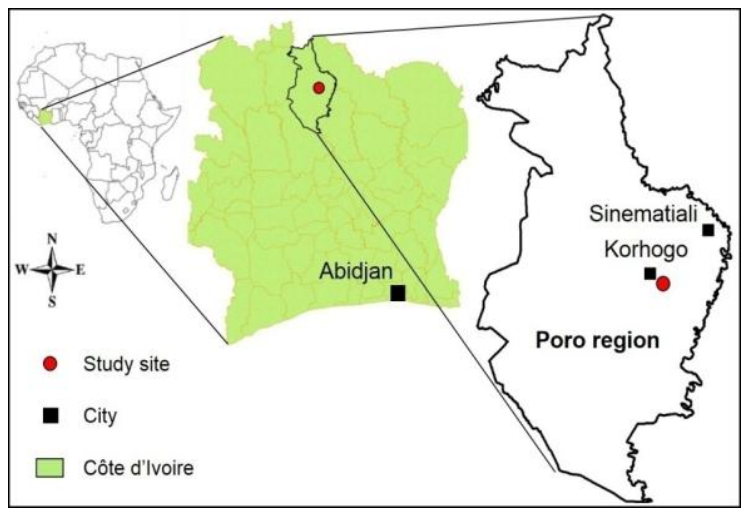

Figure 1 Systematic representation of the study site
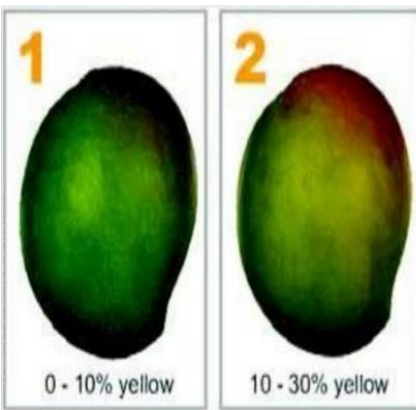

yellow
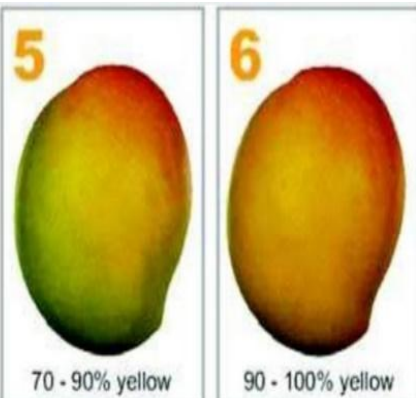

$90 \cdot 100 \%$ yellow
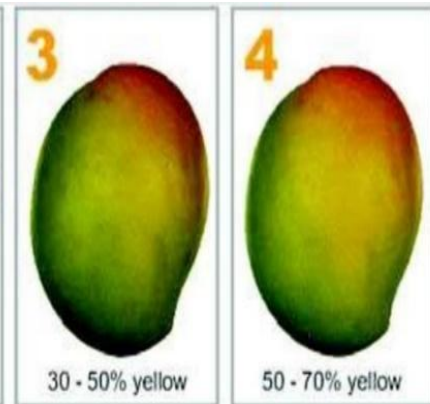

$50 \cdot 70 \%$ yellow

\subsection{Fruit sampling}

To determine the harvest date of the fruits, the opening date of the last flower (terminal flower) of 1645 inflorescences was recorded at random in the crown and at ground level on 15 mango trees in January 2019. Because of the natural physiological decline of the mango tree and very low rate of fruit set of hermaphrodite flowers, 240 fruits obtained from these 1645 inflorescences were harvested during the following mango season in April 2019 at 90, 95, 100, and 105 days after the opening of the terminal flower (60 fruits per date). The mangoes harvested at less than 90 days after flowering, are generally immature, and the time between flowering and fruit maturity is from 3 to 6 months depending on the variety and the climatic conditions (Mukherjee \& Litz, 2009). Batches of 60 fruits thus harvested at each date were sent to the CNRA laboratory in Lataha for morphological and physicochemical analyses. Measurements and observations were directly made at harvest on half of these fruits. The other half was kept in a well-ventilated room (room temperature: $28.8 \pm 1.2^{\circ} \mathrm{C}$ ) at the Lataha station, out of direct sunlight for ripening, until the fruits had a reddish-yellow skin color (Figure 2; IIC scale: International Import Company). The mangoes sampled were individually treated in each batch, and all 60 fruits were measured.

\subsection{Morpho-physical measurements made on fruits}

\subsubsection{Fruit morphology}

The variables considered for the assessment of fruit morphology were length, width, circumference, and fruit mass (Figure 3A). These measurements were carried out using a sliding caliper (Model: Vernier Caliper; precision: $0.02 \mathrm{~mm}$ ), and total fruit mass was measured using a precision scale (Model: PPS2102C; precision: $0.01 \mathrm{~g}$ ).

\subsubsection{Fruit volume}

The cylinder approximation analysis method was used in this study to estimate mango volume. The volume was determined by considering the fruit as a cylinder, as can be seen in Figure 3B (Sa'ad et al., 2015). Thus, the volume and the specific gravity of the fruit were assessed using Equations 1and 2, respectively.

\subsubsection{Fruit density measured by flotation test}

A flotation test was carried out on each fruit (Figure 3C). This test consisted of plunging each mango into a tank and observing whether it sank or floated. The density of each fruit was calculated according to Equation 3. 
A

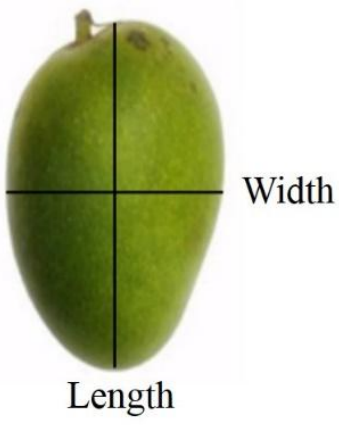

B

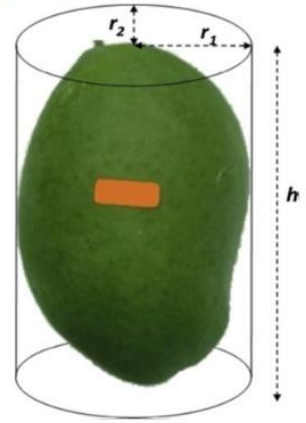

C

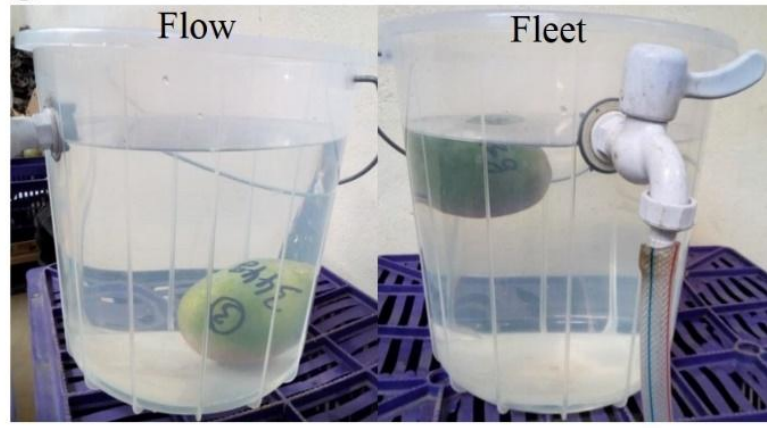

Figure 3 Morpho-physical fruit measurements. (A) fruit size; (B) fruit volume; and (C) fruit density
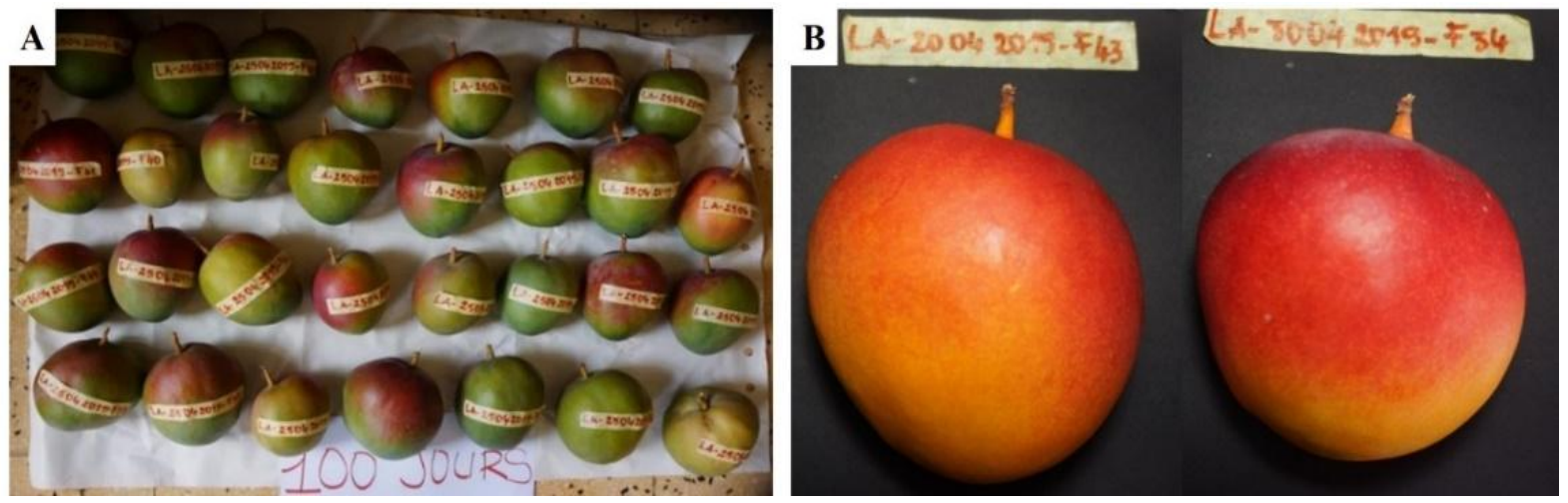

Figure 4 (A) Fruits exposed to room temperature; (B) Ripe fruits.

(Eq. 1)

$$
\mathrm{V}\left(\mathrm{cm}^{3}\right)=\pi \mathrm{r}^{2} \mathrm{~h}
$$

where:

$\mathrm{V}=$ estimated mango volume

$\mathrm{r}=$ radius $\mathrm{h}=$ height

(Eq. 2)

$$
\rho\left(\mathrm{g} / \mathrm{cm}^{3}\right)=\frac{\mathrm{m}}{\mathrm{V}}
$$

where:

$\rho=$ mango specific gravity

$\mathrm{V}=$ estimated mango volume

$m=$ mango mass

(Eq. 3)

$$
\mathrm{d}=\frac{\rho}{\rho \text { eau }}
$$

where:

$d$ = mango density

$\rho=$ mango specific gravity

$\rho e a u=$ specific gravity of water

\subsection{Stored batches: ripening time, mass loss rate and} appearance of fruit skin

Ripening time (in days) was observed for each batch stored at room temperature $\left(28.8 \pm 1.2^{\circ} \mathrm{C}\right)$ as of the harvest date until the fruits turned yellow to yellow-orange and their pulp began to soften (Figure 4). The average ripening time was observed for the first ripe fruit and the last ripe fruit of the batch, with ripening periods corresponding to each fruit. The mass of each fruit was determined before and after ripening using a precision scale. The mass-loss rate was calculated according to Equation 4 . The wrinkled or normal appearance of the fruit skin was assessed by observation at the end of ripening.

(Eq. 4)

$$
\operatorname{Pm}(\%)=\frac{m_{i}-m_{f}}{m_{i}} \times 100
$$

where:

Pm $=$ mass loss

$m_{i}=$ fruit mass at harvest

$m_{f}=$ fruit mass after ripening

\subsection{Physicochemical fruit measurements}

\subsubsection{Soluble sugar content at harvest and after ripening}

Soluble sugar content was estimated in degrees Brix with a benchtop refractometer (Atago RX-5000; precision: 0.01\%). The mango was placed with its back shoulder towards the operator, and a longitudinal cut was made just next to the pit on the right side, 
from the level of the stalk to the apex. Using a small knife, the entire content of the pulp of the two mango parts was carefully scraped to obtain a paste representative of all of the pulp. The paste obtained was pressed in a little piece of white fabric and the degree Brix was directly measured on 2 to 3 drops of juice on the refractometer prism. Three measurements were made for each mango.

\subsubsection{Dry matter content at harvest and after ripening}

The fruit was peeled and cut into longitudinal slices over its entire length, in such a way as to represent the fruit in its entirety. These slices were cut into small cubes and mixed well, from this 20 to 30 $\mathrm{g}$ of this pulp were then removed, weighed, and dried in an oven in aluminum foil $\left(75^{\circ} \mathrm{C}\right)$ for 3 days. Dry matter content was calculated using Equation 5.

(Eq. 5)

$$
\operatorname{DM}(\%)=\frac{m_{\mathrm{f}}-\mathrm{m}_{\mathrm{a}}}{\mathrm{m}_{\mathrm{e}}} X 100
$$

where:

$\mathrm{DM}=$ dry matter content

$\mathrm{m}_{\mathrm{f}}=$ final mass obtained after drying, i.e., the mass of the aluminum foil and the mass of the heated sample (in g)

$\mathrm{m}_{\mathrm{a}}=$ mass of the aluminum foil (in $\mathrm{g}$ )

$\mathrm{m}_{\mathrm{e}}=$ mass of the fresh sample placed in the aluminum foil before drying (in $g$ )

\subsection{Statistical analyses}

An analysis of variance (ANOVA) was carried out to test the significance (at the 0.05 threshold) of the effect of harvest date on each of the morphological and physicochemical parameters. The Student-Newman-Keuls (SNK) comparison test was used to compare the means between the harvest dates. Statistical analyses were carried out using Statistica software, version 7.1.

\section{Results}

\subsection{Morphological and physical characterization of the fruits}

Except for specific gravity, fruits harvested at 100 days after flowering registered the highest average values, and fruits harvested at 90 days after flowering registered the lowest values for the set of parameters measured (Table 1). As a matter of fact, mass $\left(\mathrm{m}_{\mathrm{i}}\right.$ : at harvest; and $\mathrm{m}_{\mathrm{f}}$ : after-ripening), length, and circumference do not differ for mangoes harvested at 95, 100, and 105 after flowering. However, these parameters are significantly lower $(\mathrm{p}<0.05)$ for mangoes harvested at 90 days after flowering. Thus, the average mass at harvest was $470.27 \pm 29.08 \mathrm{~g}$ for mangoes harvested at 90 days, whereas that of mangoes harvested at 95, 100, and 105 days after flowering was $557.93 \pm 20.62 \mathrm{~g}$. The average length of fruit at harvest was $10.11 \pm 1.34 \mathrm{~cm}$ at 90 days, and 10.99 $\pm 0.89 \mathrm{~cm}$ for mangoes harvested at 95,100 , and 105 days after flowering. The average circumference of the fruits was $28.38 \pm$ $2.46 \mathrm{~cm}$ at 90 days, whereas it was $30.61 \pm 2.19 \mathrm{~cm}$ for mangoes harvested at 95, 100, and 105 days after flowering. The volume and the width do not differ for mangoes harvested at 95 and 105 days after flowering. Nevertheless, these parameters were significantly lower $(\mathrm{p}<0.05)$ for mangoes harvested at 90 days, and higher for mangoes harvested at 100 days after flowering. Consequently, the average volume and the average width of fruits at harvest was $353.91 \pm 19.72 \mathrm{~cm}^{3}$ and $9.3 \pm 0.88 \mathrm{~cm}$, respectively, for mangoes harvested at 90 days after flowering, whereas they were $401.44 \pm 15.32 \mathrm{~cm}^{3}$ and $9.59 \pm 0.68 \mathrm{~cm}$, respectively, for mangoes harvested at 95 and 105 days after flowering. The average volume and the average width of the fruits at harvest were $428.58 \pm 14.40 \mathrm{~cm}^{3}$ and $9.87 \pm 0.65 \mathrm{~cm}$, respectively, for mangoes harvested at 100 days after flowering. The average specific gravity at harvest did not significantly differ for the four harvest dates. The average value obtained for these four dates was $1.36 \pm 0.16 \mathrm{~g} / \mathrm{cm}^{3}$.

\subsection{Flotation test, density and fruit appearance}

The results of the flotation test on fruit appearance at harvest are presented in figure 5. Overall, the number of floating and wrinkled fruits decreases with the length of the harvest date. At 90 days after flowering, 26 fruits out of 30 floated on the water, whereas only 15 and 17 fruits out of 30 floated at 100 and 105 days after flowering, respectively. As for fruit appearance during ripening storage, the number of wrinkled fruits during ripening increased from 13 to 30 at 90 days, and 1 wrinkled fruit out of 30 at 105 days after flowering. Results revealed that the density does not significantly differ for the four harvest dates $(\mathrm{p}>0.05)$.

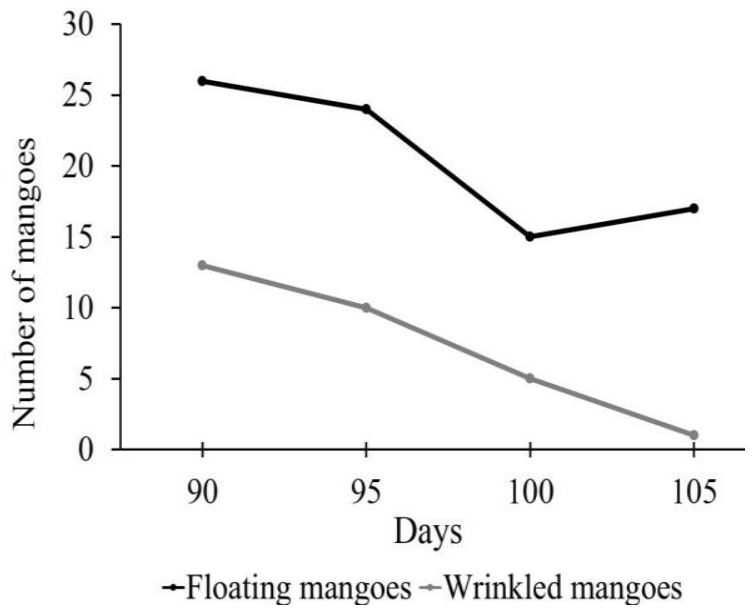

Figure 5 Number of floating and wrinkled fruits as a function of harvest date 
Table 1 Morphological and physical characteristics of fruits

\begin{tabular}{|ccccccc|}
\hline Variables/Harvest date (day) & 90 & 95 & 100 & 105 & $\mathrm{~F}$ & $\mathrm{p}$ \\
\hline $\mathrm{m}_{\mathrm{i}}(\mathrm{g})$ & $470.27 \pm 29.08 \mathrm{a}$ & $542.00 \pm 21.25 \mathrm{~b}$ & $572.46 \pm 20.27 \mathrm{~b}$ & $557.93 \pm 20.62 \mathrm{~b}$ & 3.85 & 0.01 \\
\hline $\mathrm{m}_{\mathrm{f}}(\mathrm{g})$ & $394.7 \pm 17.20 \mathrm{a}$ & $472.23 \pm 17.92 \mathrm{~b}$ & $514.76 \pm 17.99 \mathrm{~b}$ & $504.36 \pm 18.73 \mathrm{~b}$ & 9.13 & 0.01 \\
\hline Volume $\left(\mathrm{cm}^{3}\right)$ & $353.91 \pm 19.72 \mathrm{a}$ & $397.62 \pm 15.66 \mathrm{ab}$ & $428.58 \pm 14.40 \mathrm{~b}$ & $405.27 \pm 14.99 \mathrm{ab}$ & 3.65 & 0.01 \\
\hline$\rho\left(\mathrm{g} / \mathrm{cm}^{3}\right)$ & $1.37 \pm 0.39 \mathrm{a}$ & $1.36 \pm 0.09 \mathrm{a}$ & $1.33 \pm 0.08 \mathrm{a}$ & $1.38 \pm 0.09 \mathrm{a}$ & 0.24 & 0.86 \\
\hline Length $(\mathrm{cm})$ & $10.11 \pm 1.34 \mathrm{a}$ & $10.99 \pm 1.02 \mathrm{~b}$ & $11.09 \pm 0.78 \mathrm{~b}$ & $10.91 \pm 0.87 \mathrm{~b}$ & 5.67 & 0.01 \\
\hline Width $(\mathrm{cm})$ & $9.3 \pm 0.88 \mathrm{a}$ & $9.52 \pm 0.67 \mathrm{ab}$ & $9.87 \pm 0.65 \mathrm{~b}$ & $9.66 \pm 0.69 \mathrm{ab}$ & 3.24 & 0.02 \\
\hline Circ. $(\mathrm{cm})$ & $28.38 \pm 2.46 \mathrm{a}$ & $30.02 \pm 2.13 \mathrm{~b}$ & $31.01 \pm 2.17 \mathrm{~b}$ & $30.80 \pm 2.29 \mathrm{~b}$ & 8.30 & 0.01 \\
\hline
\end{tabular}

Mean \pm SE value followed by the different letter in the same vertical column are significantly different according to the StudentNewman-Keuls test $(\mathrm{P}=0.05)$

\subsection{Ripening time and weight loss of fruits}

Ripening time and weight loss of fruits as a function of their harvest date are presented in Figures 6 and 7. Results revealed that ripening time and mass loss decrease continuously with the length of the harvest date of the fruits. The onset of ripening of the harvested fruits at 90 days after flowering lasts for an average of 15 days, and then progressively decreases, reaching 10 days at 105 days after flowering. As for mass loss, mangoes assessed at different harvest dates showed a wide range of variability $(\mathrm{p}<0.05$ with $\mathrm{p}=0.01)$. Fruits harvested at 90days $(14.05 \pm 8.57 \%)$ and at

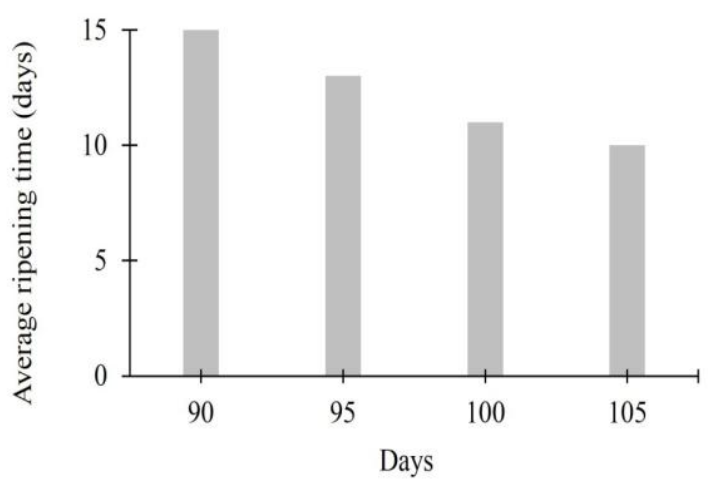

Figure 6 Average fruit ripening time as a function of harvest date
95 days $(12.60 \pm 5.43 \%)$ after flowering lost more mass than the fruits harvested at 100 days $(10.04 \pm 1.64 \%)$ and at 105 days $(9.60$ $\pm 2.17 \%$ ) after flowering.

\subsection{Physicochemical characterization of fruits}

By determining the physicochemical parameters such as the degree Brix and the dry matter of the mango pulp, we were able to assess the physicochemical quality of the mangoes as a function of the harvest date of the fruits (Table 2). In general, the degrees Brix at harvest (Brix 1), indicating the sugar content of the fruits, revealed

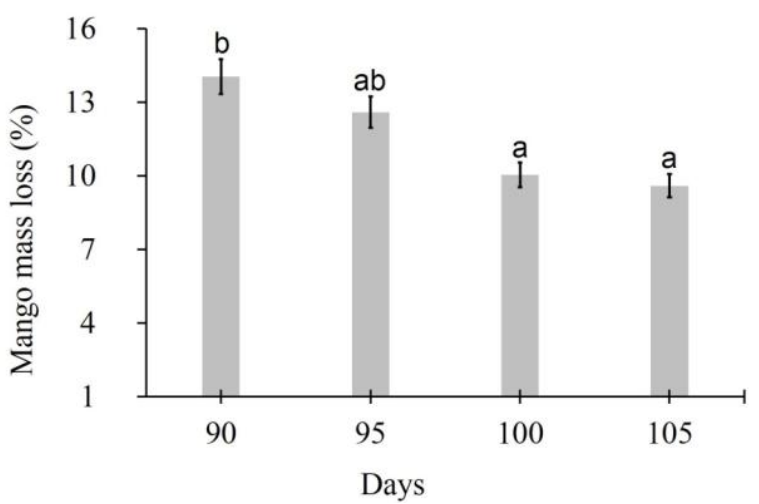

Figure 7 Average fruit weight loss as a function of harvest date Different letters indicate statistically significant difference (Student-Newman-Keuls test, $\mathrm{P}=0.05$ )

Table 2 Physicochemical characteristics of mango pulp

\begin{tabular}{|ccccccc|}
\hline Variables/Harvest date (day) & 90 & 95 & 100 & 105 & $\mathrm{~F}$ & $\mathrm{p}$ \\
\hline Brix 1(\%) & $8.67 \pm 0.79 \mathrm{a}$ & $9.06 \pm 0.91 \mathrm{a}$ & $9.11 \pm 0.98 \mathrm{a}$ & $9.13 \pm 0.97 \mathrm{a}$ & 1.69 & 0.17 \\
\hline Brix 2 $(\%)$ & $16.55 \pm 1.39 \mathrm{a}$ & $17.85 \pm 1.24 \mathrm{~b}$ & $18.77 \pm 1.85 \mathrm{c}$ & $19.82 \pm 0.99 \mathrm{~d}$ & 29.22 & 0.01 \\
\hline DM 1 (\%) & $17.20 \pm 1.27 \mathrm{a}$ & $17.34 \pm 1.34 \mathrm{a}$ & $19.10 \pm 0.93 \mathrm{~b}$ & $18.54 \pm 2.88 \mathrm{~b}$ & 8.13 & 0.01 \\
\hline DM 2 (\%) & $17.25 \pm 1.33 \mathrm{a}$ & $19.50 \pm 1.49 \mathrm{~b}$ & $20.36 \pm 1.92 \mathrm{c}$ & $20.80 \pm 1.26 \mathrm{c}$ & 32.22 & 0.01 \\
\hline
\end{tabular}

Mean \pm SE value followed by the different letter in the same vertical column are significantly different according to the StudentNewman-Keuls test $(\mathrm{P}=0.05)$ 
a slight, non-significant increase $(\mathrm{p}>0.05$ where $\mathrm{p}=0.17)$, from $8.67 \pm 0.79 \%$ to $9.13 \pm 0.97 \%$ on average, at 90 and 105 days after flowering, respectively. After fruit ripening, significantly different Brix averages (Brix 2) were observed from one harvest date to another: Brix increased from $16.55 \pm 1.39 \%$ at 90 days after flowering, to $19.82 \pm 0.99 \%$ at 105 days after flowering, respectively.

As for the dry matter content at harvest (DM1) and after fruit ripening (DM2), significant differences were observed for the four harvest dates studied $(\mathrm{p}<0.05)$. For the dry matter at harvest, the values were $17.20 \pm 1.27 \%, 17.34 \pm 1.34 \%, 19.10 \pm 0.93 \%$, and $8.54 \pm 2.88 \%$, respectively, for fruits harvested at $90,95,100$, and 105 days after flowering. The values for dry matter after ripening were $17.25 \pm 1.33 \%, 19.50 \pm 1.49 \%, 20.36 \pm 1.92 \%$, and $20.80 \pm$ $1.26 \%$, respectively, for fruits harvested at $90,95,100$, and 105 days after flowering.

\section{Discussion}

\subsection{Morphological and physical evolution of the fruits}

Fruits harvested at 100 days after flowering registered higher average values as compared to the fruits harvested at 90 days after flowering. This variability shows that mangoes did not have the same level of maturity and growth rate at harvest. These results could be explained by the consequences of competition between fruits for assimilates such as carbon and nitrogen (Ngoa et al., 2021). Indeed, the volume and mass of the fruit increase with the amount of available assimilate. Consequently, the final mass and composition of the fruit depending on the availability of carbon and nitrogen, which depend on the photosynthetic functioning of the leaves, the number of fruits, and, especially the fruit load that leads to competition between fruits for assimilates (Sun et al., 2021; Wen et al., 2021). In our case study, the variability observed could be because mangoes harvested from 100 days after flowering benefited from slightly more carbon and nitrogen. This is explained by the decrease of the fruit load which leads to competition between fruits.

For mango density, we observed almost identical values for the four harvest dates presented $\left(1.33 \pm 0.08 \mathrm{~g} / \mathrm{cm}^{3}\right.$ at 100 days to $1.38 \pm 0.09 \mathrm{~g} / \mathrm{cm}^{3}$ at 105 days). These values are comparable to those of $0.99 \pm 0.030 \mathrm{~g} / \mathrm{cm}^{3}$ to $1.12 \pm 1.02 \mathrm{~g} / \mathrm{cm}^{3}$ observed by Passannet et al. (2018) in the study of the variability of the physical characteristics of cultivated mangoes (Smith, Kent, Keitt, Palmer, Valencia, etc.) in Tchad. This low density of mangoes could enable fruits to float and facilitate their largescale cleaning in tanks (Diakabana et al., 2013). Thus, fruit density, measured at the mature green stage, could be useful for the fresh fruit sector for grading or sorting mangoes early in the supply chain.

\subsection{Skin appearance, mass loss and ripening time}

Results showed that the onset of fruit ripening extends over 15 days when the fruits are harvested at 90 days after flowering, and over 10 days when the fruits are harvested at 105 days. These values are comparable to those found by Abu et al. (2020) for Kent mangoes in Ghana. They observed a ripening time of 10 days for 'Kent' harvested at the physiological maturity stage. They pointed out that the differences in ripening time between fruits could be due to their physiological ripening periods. In the case of climacteric fruit, such as mango, the fruit requires a ripening period of generally 8 to 10 days at about $25^{\circ} \mathrm{C}$ before it reaches the desired taste and texture at the time of consumption. This ripening time interval was observed in mangoes harvested at 100 and 105 after flowering in our case study. The mass loss also varied from $14.05 \%$ at 90 days, to $9.60 \%$ at 105 days after flowering, showing that the fruit mass loss decreases in proportion with the duration of the flowering-harvest interval.

Moreover, results revealed that the number of wrinkled fruits decreased with the duration of the flowering-harvest interval (going from 13 wrinkled fruits out of 30 at 90 days, to 1 wrinkled fruit out of 30 at 105 days after flowering). The considerable mass loss and the high proportion of wrinkled fruits observed for the mangoes harvested at 90 and 95 days after flowering and could be due to the obvious effect of extended storage due to late ripening and physiological immaturity. According to Brecht (2020) and Abu et al. (2020), the loss of fruit mass during storage is a consequence of the loss of food reserves stored in the fruit during respiration and acceleration of senescence when the reserves that provide the energy to maintain the living state of the fruit are depleted. Also, less mature mangoes are less filled with reserve substances and are therefore much more likely to experience a higher rate of transpiration and water loss during storage. Vannière et al. (2013) and Abu et al. (2021) observed that fruits with an inadequate level of physiological maturity will have a partially or white colored pulp during ripening, and will most certainly never acquire good organoleptic qualities, especially in terms of their vitamin $\mathrm{A}$ and $\mathrm{C}$ content.

\subsection{Increase of the degree Brix and dry matter during fruit ripening}

The experiment consisted of making a physicochemical characterization of fruit pulp at different harvest dates. At harvest, a slight variation of the degree of Brix $(8.67 \pm 0.79 \%$ Brix at 90 days, to $9.13 \pm 0.97 \%$ Brix at 105 days after flowering) was observed. However, after ripening, highly significant differences in the degree Brix were observed $(16.55 \pm 1.39 \%$ Brix at 95 days, to $19.82 \pm 0.99 \%$ Brix at 105 days after flowering). These results indicate that there is a low production of soluble sugars from starch stored in the mango before its harvest and that this is true, 
regardless of its level of maturity. Sugar content after-ripening is greater when fruits are harvested later and, therefore, when the ripening time after harvest is shorter. Sugar content seems to increase in proportion with the duration of the flowering-harvest interval of mangoes at harvest. The Brix values observed are comparable to those found by Tasie et al. (2020) for mango cv. 'Kent' harvested at maturity. The authors reported soluble sugar contents levels of $18 \%$ Brix after fruit ripening.

These results are similar to the results of Abu et al. (2021) studies, those who carried out a study on Kent mangoes harvested at physiological maturity in Ghana. The author found soluble sugar contents of $7 \%$ Brix at harvest, and $18 \%$ Brix after the ripening of Kent mangoes harvested at 126 days after flowering. These values are very close to those obtained in this study for mangoes harvested at 100 and 105 days after flowering, and thus show that the Kent mango harvested as of 100 days after flowering is very rich in sugar. The degree of Brix remains a key criterion in the evaluation of the sweet taste of the fruits. In fact, according to Diop et al. (2021) and Abu et al. (2021), fruits harvested at an advanced stage of maturity are richer in soluble sugars, dry matter, and starch than those harvested earlier, as is the case in the present study. The authors indicated that the harvesting of mangoes for export should be established based on the type of market, the distance from the orchard or packing house, and the type of transport to be used. These authors suggested that mangoes should be harvested at the ideal stage to allow the development of the most adequate organoleptic quality and the longest post-harvest life. Nevertheless, high sugar content presents the risk of degradation by yeasts in the event of poor conservation conditions (Koné et al., 2018). For the dry matter, highly significant differences were observed at harvest (between 17 and 19\%) and after fruit ripening (between 17 and 20\%). These results are similar to those of Tasie et al. (2020) for 'Kent' mango. Indeed, these researchers found a dry matter value between 16 and $18 \%$. The mature 'Kent' mango was therefore characterized by relatively low water content in the pulp, which could explain its good conservation time.

\section{Conclusion}

This study of the effect of harvest date on ripening and mango quality made it possible to characterize the morphological, physical, and chemical conditions of the fruits, and to analyze their suitability during ripening. In light of the results obtained, 100 days after the opening of the last flower of the inflorescence appears to correspond to the beginning of the physiological maturity of the 'Kent' mango in northern Côte d'Ivoire. As of this period, the fruit will acquire better organoleptic qualities during post-harvest ripening. Consequently, this period appears to be the optimal harvest date to obtain mangoes rich in sugar, with smooth skin, low mass loss, and a short ripening time. To sum up, mangoes harvested at this time would therefore have an optimal organoleptic quality after ripening.

\section{Acknowledgments}

This study was carried out within the framework of Phase 7 of the project, CNRA-CIRAD/C2D Fruits \& Market Gardening (Development Support for Agricultural Research), of the $2^{\text {nd }}$ project for Support for the Modernization and Reform of Universities and Higher Education Institutions of Côte d'Ivoire (AMRUGE-CI $\mathrm{N}^{\circ} 2$ ), financed by the Debt Reduction-Development Contract (C2D) between Côte d'Ivoire and France. This work was also supported by the project Pre-Maturation PixFruit App financed by the French Région Occitanie.

\section{Conflict of interest}

The authors declare that they have no conflict of interest arising out of this study

\section{References}

Abu M, Abbey DL, Amey KN (2021) Relation of harvesting time on physicochemical properties of Haden, Kent, Palmer and Keitt mango varieties for export and local markets. Journal of Horticulture and Postharvest Research 4 (1): 87-100.

Abu M, Olympio NS, Darko OJ (2020) Effects of different storage temperature conditions on ripening quality and shelf life of mango (Mangifera indica) fruits in Ghana. Journal of Horticulture and Postharvest Research 3 (2): 245-256.

Bender RJ, Brecht JK, Sargent SA (2021) Low storage temperature for tree ripe mangoes under controlled atmospheres with elevated $\mathrm{CO} 2$ concentrations. Journal of the science of food and agriculture 101 (3): 1161-1166

Brecht KJ (2020) Mango postharvest best management practices manual. University of Florida USA Pp.73.

Cissé M, Silue Y, Cissé M, Kouadio ADS, Nindjin C (2020) Effect of Calcium Carbide Treatment on Ripening Time and Physicochemical Properties of Mango (Mangifera indica L.) Variety "Kent", Côte d'Ivoire. Current Journal of Applied Science and Technology 39 (38): 24-30

Cortés V, Ortiz C, Aleixos N, Blasco J, Cubero S, Talens P (2016) A new internal quality index for mango and its prediction by external visible and near-infrared reflection spectroscopy. Postharvest Biology Technological 118: 148-158.

Diakabana P, Kobawila SC, Massengo V, Louembe D (2013) Effet du degré de maturation sur la cinétique de fermentation éthylique 
de la pulpe de mangue cultivar Boko. Cameroon Journal of Experimental Biology 09 (01): 1-8.

Diop A, Méot JM, Léchaudel M, Chiroleu F, Diop Ndiaye DN, Mertz C, Cissé M, Chillet M (2021) Impact of Preharvest and Postharvest on Color Changes during Convective Drying of Mangoes.Foods 10: 490.

Djaha AJB, N'da HA, Koffi KE, Adopo AA, Ake S (2014) Diversité morphologique des accessions d'anacardier (Anacardium occidentale L.) introduits en Côte d'Ivoire. Revist Ivoire Sciences Technological 23: 244-258.

Farina V, Gentile C, Sortino G, Gianguzzi G, Palazzolo E, Mazzaglia A (2020) Tree-ripe mango fruit: physicochemical characterization, antioxidant properties and sensory profile of six Mediterranean-grown cultivars. Agronomy 10: 884.

Ibrahima B, Mouhamadou F, Moussoukhoye D (2020) Study of the variation in total and reducing sugars contents according to the variety and according to the position where the fruit (mango) was harvested from five mango varieties exploited in Senegal. Journal of Biosciences and Medicines 8: 28-36.

Koné HS, Koné KY, Akaki KD, Soro D, Elleingang FE, Assidjo NE (2018) Caractérisation biochimique de la pulpe des fruits du prunier noir (Vitex Doniana) de la Côte d'Ivoire. European Scientific Journal January14 (3): 1857-7881.

Kouamé ML, Kouamé KA, Ouattara L, N'guessan KF, AlloueBoraud WM, Dje KM (2020) Contraintes liées à la production et à la commercialisation des mangues (Mangifera indica) en Côte d'Ivoire : cas des variétés exportées vers l'Europe. Afrique Science 17 (3): 16-27.

Mitra SK (2016) Mango production in the world-present situation and future prospect. Acta Horticulturae 287-296.

Mukherjee SK, Litz RE (2009) Introduction: Botany and Importance. In The Mango: Botany, Production and Uses, 2 (Ed), (CAB International, Wallingford) Pp. 1-18.

Nambi VE, Thangavel K, Manickavasagan A, Shahir S (2017) Comprehensive ripeness index for prediction of ripening level in mangoes by multivariate modelling of ripening behaviour. International Agrophysics 31 (1): 35-44.

Ngao J, Martinez S, Marquier A, Bluy S, Saint-Joanis B, Costes E, Pallas B (2021) Spatial variability in carbon- and nitrogen-related traits in apple trees: the effects of the light environment and crop load. Journal of Experimental Botany 72 (5): 1933-1945.
Nordey T, Davrieux F, Léchaudel M (2019) Predictions of fruit shelf life and quality after ripening: Are quality traits measured at harvest reliable indicators? Postharvest Biology and Technology 153: 52-60.

Nordey T, Léchaudel M, Génard M, Joas J (2016) Factors affecting ethylene and carbon dioxide concentrations during ripening: Incidence on final dry matter, total soluble solids content and acidity of mango fruit. Journal of Plant Physiology 196 (197): 70-78.

Parrot L, Klaver D, Biard Y, Kabré E, Vannière H (2018) Analyse de la chaine de valeur Mangue au Burkina Faso. Value Chain Analysis for Development, n², Pp.6.

Passannet AS, Aghofack-Nguemezi J, Gatsing D (2018) Variabilité des caractéristiques physiques des mangues cultivées au Tchad : caractérisation de la diversité fonctionnelle.Journal of Applied Biosciences 128: 12932 -12942.

Raghavendra A, Guru DS, Rao KM (2021) An automatic predictive model for sorting of artificially and naturally ripened mangoes. In: Bhateja V, Peng SL, Satapathy SC, Zhang YD (eds) Evolution in Computational Intelligence. Advances in Intelligent Systems and Computing 1176. Springer, Singapore.

Sa'ad FSA, Ibrahim MF, Shakaff AYM, Zakaria A, Abdullah MZ (2015) Shape and weight grading of mangoes using visible imaging. Computers and Electronics in Agriculture 115: 51-56.

Subedi PP, Walsh KB, Owens GP (2007) Prediction of mango eating quality at harvest using short wave near infrared spectrometry. Postharvest Biology Technological 43: 326-334.

Sun W, Xu Z, Ibell P, Bally I (2021) Genetic and environmental influence on foliar carbon isotope composition, nitrogen availability and fruit yield of 5-year-old mango plantation in tropical Australia. Journal of Soils and Sediments1614-7480.

Tasie MM, Alemimi AB, Ali RM, Takeoka G (2020) Study of physicochemical properties and antioxidant content of mango (Mangifera indica L.) fruit. Eurasian Journal of Food Science and Technology 4 (2): 91-104.

Vannière H, Rey JY, Vayssieres JF (2013) Itinéraire technique mangue (Mangifera indica L.). www.coleacp.org/pip, Pp. 64

Wen Y, Su SC, Jia TT, Wang XN (2021) Allocation of photoassimilates in bud and fruit from different leaf nodes of camellia oleifera. American Society for Horticultural Science 1-9. 